\title{
ЗНАЧЕННЯ ЕКОНОМІКИ ЗАМКНЕНИХ ЦИКЛІВ ДЛЯ ПОМ'ЯКШЕННЯ ТА АДАПТАЦЇ̈ ДО ЗМІН КЛІМАТУ: ГЛОБАЛЬНІ ТЕНДЕНЦІЇ, МОЖЛИВОСТІ ТА ПЕРЕСТОРОГИ
}

Економіка замкнених циклів $є$ концепцією управління ресурсами, що стрімко набуває глобальної популярності та може зовсім скоро стати ключовим рушієм для досягнення цілей Паризької угоди. Розглянуто можливості та перестороги щодо застосування науково обгрунтованої концепції економіки замкнених циклів для заходів із пом'якшення та адаптації до змін клімату. Обгрунтовано внесок економіки замкнених циклів до нового розуміння змін клімату, поглиблення та розширення спектра рішень у цій сфері, виявлення нових взаємозв'язків між різними галузями та секторами, а також застосування цих можливостей для проривних та інноваційних практик, які максимізують позитивні впливи та зводять до мінімуму екологічні ризики. Проаналізовано особливості концепції економіки замкнених циклів, які сприяють залученню широкого кола зацікавлених сторін (представників органів влади, бізнесу, науки, громадськості) та активному діалогу між ними. Звернено увагу на істотні аспекти застосування концепції для пом'якшення та адаптації до змін клімату, можливості для синергій між енергетичною, економічною, екологічною, ресурсною та іншими політиками в ширших рамках цілісної політики сталості. З'ясовано обмеження та актуальні виклики, що пов'язані з тлумаченням, практичним втіленням і науковими засадами концепції. Запропоновано ключові напрями застосування економіки замкнених циклів для стратегій щодо пом'якшення та адаптації до змін клімату.

Ключові слова: екологічна економіка; сталий розвиток; інновації; технології; управління.

Вступ. В умовах пришвидшення змін клімату на планеті зростає потреба у прийнятті дієвих рішень для реалізації цілей Паризької Угоди (UNFCCC, 2015). Для уникнення потепління на $2^{\circ} \mathrm{C}$ до 2030 р., викиди парникових газів потрібно скоротити до рівня 41,8 млрд тонн $\mathrm{CO}_{2} \mathrm{e}$ (еквівалента) на рік, тоді як найбільш оптимістичний сценарій перевищує цю цифру на 11 млрд тонн $\mathrm{CO}_{2}$ е на рік (UNEP, 2017). Щоб уникнути підвищення температури на $1,5^{\circ} \mathrm{C}$ річні скорочення мають збільшитись ще на 5,3 млрд тонн $\mathrm{CO}_{2}$ е на рік (UNEP, 2017). Вибір підходів, які сприятимуть впровадженню ефективних, стійких та адаптивних рішень, є складним завданням (Huitema et al., 2016), адже, поряд із кліматичними цілями, потрібно забезпечувати інші позитивні впливи, мінімізувати ризики та негативні наслідки (Geneletti \& Zardo, 2016). Такий підхід відображено в концепції економіки замкненого циклу (ЕЗЦ), заснованої на принципах оптимізації використання ресурсів, мінімізації відходів та екологічних ризиків. Від першої згадки ЕЗЦ минуло 28 років (Pearce \& Turner, 1990), втім тільки після офіційного впровадження у СС ії популярність стрімко зросла (ЕС, 2015), а світові лідери поступово усвідомлюють іiі значущість для досягнення сталого розвитку (WEF, 2014)

Мета роботи - розроблення теоретико-методологічних засад реалізації концепції економіки замкненого циклу для пом'якшення та адаптації до змін клімату.

Викладення основного матеріалу. Сьогодні концепцію ЕЗЦ часто розглядають як панацею від пов'язаних із ресурсами викликів. Її використовують у формуванні еколого-економічної політики таких держав, як Японія, Китай, Індія, Франція, Італія, Нідерланди, Швеція та Канада. Численні компанії також застосовують їі для стратегій свого розвитку (Lewandowski, 2016).

Ключовою ідеєю ЕЗЦ є перехід від лінійної моделі "зроби - використай - викинь" до моделі двох взаємопов'язаних кіл - де біологічні ресурси безпечно повертаються у довкілля, а технологічні можуть брати участь у майже нескінченних процесах повторного використання та перероблення. Вчені (Merli, Preziosi \& Acampora, 2018) виділяють три основні сфери дії ЕЗЦ: зміна соціальної та економічної динаміки на макрорівні, творення індустріальних симбіозів та нових форм взаємодії на мезорівні та стимулювання нових способів функціонування бізнесу на мікрорівні.

Розстановка пріоритетів відбувається згідно з ієрархією використання ресурсів, метою якої є максимальне збереження цінності та вартості продуктів, обладнання або їх деталей на всіх етапах життєвого циклу. До інструментів ЕЗЦ відносять реверсну логістику, дизайн виробів (Blok et al., 2016), "зелені тарифи" для підприємств, які використовують вторинну сировину, змі-

\section{Інформація про авторів:}

Соловій Віталій Ігорович, аспірант, кафедра екологічної економіки. Email: vitsoloviy@yahoo.com; https://orcid.org/0000-00024216-3735

Цитування за ДСту: Соловій В. І. Значення економіки замкнених циклів для пом'якшення та адаптації до змін клімату: глобальні тенденції, можливості та перестороги. Науковий вісник НлтУ України. Серія Економічна. 2018, т. 28, № 4. С. 116-120

Citation APA: Soloviy, V. І. (2018). The Significance of Circular Economy for Climate Change Mitigation and Adaptation: Global Trends, Possibilities and Precautions. Scientific Bulletin of UNFU, 28(4), 116-120. https://doi.org/10.15421/40280422 
щення оподаткування з праці на ресурси (EMF, 2015), оновлення бізнес-моделей (Boken et al., 2016; Lewandowski, 2016) та адаптація здобутків четвертої індустріальної революції (Ramkamur, 2017). ЕЗЦ також інтегрує наукові методи різних дисциплін, зокрема, такі, як: оцінка життєвого циклу та аналіз матеріальних потоків.

Поряд з увагою вчених до історії концепції ЕЗЦ (Winans, Kendall \& Deng, 2017), іiі міждисциплінарних особливостей (Murray et al., 2017;), принципів (Korhonen, Honkasalo \& Seppälä, 2018), трактувань (Kirchherr, Reike \& Hekkert, 2017) та потенціалу (Lewandoswki, 2016; Bocken et al., 2016), на нашу думку, варто звернути особливу увагу на чинники швидкого впровадження концепції ЕЗЦ за участі широкого кола зацікавлених сторін (науковців, підприємців, органів влади та ін.), а також вивчити обмеження та перестороги щодо її застосування. Ці аспекти буде розглянуто в контексті зміни клімату, де значущість концепції ЕЗЦ неможливо недооцінити.

Уважаємо, що одним з основних чинників швидкого поширення ЕЗЦ є властива їй бізнес-логіка. Донедавна екологічне благополуччя пов'язувалось із зниженням екологічної шкоди, втім ЕЗЦ інвертувала цей спосіб мислення і змістила фокус на позитивні заходи, які можна втілювати, водночас мінімізуючи негативні наслідки, що дає змогу орієнтуватись на найбільш творчі та проривні ідеї. Концепція ЕЗЦ є зразком лаконічності та зрозумілості, що сприяє діалогу 3 представниками державної влади та бізнесу. Такий "рефреймінг" також передбачає, що екологічні рішення можуть і повинні бути більш конкурентоспроможними (Pauli, 2010), а цінність продукції чи матеріалів не обов'язково знижується $з$ часом, а може навіть зростати (McDonough \& Braungart, 2002; 2013).

Отже, найважливішим внеском ЕЗЦ до подолання зміни клімату є зміна ставлення до природних циклів і матеріалів. Традиційно викиди парникових газів розглядають як проблему - складну, багатовекторну, політичну. В ЕЗЦ $\mathrm{CO}_{2}$ перестає бути проблемою, і натомість стає ресурсом (McDonough, 2016). На заміну звичним визначенням щодо стратегій та продуктів, таких як "безвуглецевий" (zero carbon), "низьковуглецевий" (low carbon) та "вуглецево-негативний" (carbon negative), W. McDonough пропонує три нові терміни: живий вуглець (living carbon), довговічний вуглець (durable carbon) та нестійкий вуглець (fugitive carbon). Перший бере активну участь у біологічних циклах, другий - розташований у твердих предметах, наприклад виробах із пластику, яких можна повторно використовувати або переробляти, і тільки третій є небажаним - він виникає після спалювання відходів, вирубування лісів, промислового тваринництва. W. McDonough також пропонує інвертувати логіку "вуглецевості" - корисні заходи мають стати "вуглецево-позитивними", а шкідливі "вуглецево-негативними".

Сьогодні більшість стратегій у сфері зміни клімату пов'язані з переходом на відновлювані джерела енергії, енергоефективністю, змінами у веденні лісового господарства та землекористування, дедалі більше уваги приділяють ризикованим проектам із геоінженерії. ЕЗЦ дає змогу істотно розширити спектр доступних стратегій та рішень, а також досягти багатьох супутніх позитивних ефектів. За розрахунками Circle Economy та Ecofys, сис- темне втілення ЕЗЦ може принаймні на половину зменшити прогалину між необхідним та очікуваним зменшенням викидів парникових газів (Blok et al., 2016), а згідно зі звітом Римського клубу, реалізація ЕЗЦ допоможе Фінляндії знизити викиди $\mathrm{CO}_{2}$ на $70 \%$ до 2030 р. та створити 75 тис. робочих місць, а у Франції 2/3 скорочень викидів дадуть змогу створити 500 тис. робочих місць (Wijkman, Skånberg \& Berglund, 2015).

Іншим важливим аспектом ЕЗЦ $є$ стратегія "нуль відходів" (zero waste), яку застосовують до управління відходами у понад 350 містах Свропи. Міжнародна організація Zero Waste Europe наводить переваги застосування підходу "нуль відходів" для подолання змін клімату (Simon, 2015): 1) зниження викидів парникових газів завдяки мінімізації відходів; 2) зниження викидів у виробничій сфері; 3) уникнення викидів метану завдяки компостуванню або перетворенню у біогаз органіки, краще депонування вуглецю у грунтах; 4) зменшення викидів від сміттєспалювальних заводів; 5) запобігання викидів шляхом перероблення є дешевшим, ніж заходи 3 енергоефективності та енергія вітру; 6) рішення у сфері "нуль відходів" зміцнюють місцеву економіку; 7) рішення у сфері "нуль відходів" залучають людей до подолання змін клімату.

Отже, використання концепції ЕЗЦ для пом'якшення та адаптації до змін клімату творить синергетичні взаємозв'язки між різними сферами та секторами. Втім, дуже часто ці зв'язки ще не сформовані та потребують впровадження активних інтеграційних процесів. Для прикладу, у "Національній стратегії управління відходами в Україні до 2030" (KMU, 2017) жодного разу не згадано про Паризьку угоду, зміни клімату, парникові гази чи викиди, тоді як "Концепція реалізації державної політики у сфері зміни клімату на період до 2030 року" (KMU, 2016) та "План щодо виконання Концепції реалізації державної політики у сфері зміни клімату на період до 2030 року" (KMU, 2017) не містять жодної згадки про відходи. Взаємозв'язок проявляється тільки у проекті "Стратегії низьковуглецевого розвитку України до 2050 року" (MENR, 2017), де відходи планують спалювати для виробництва теплової та електричної енергії. Отже, зазначені стратегічні документи передбачають мінімальну взаємодію та співпрацю профільних міністерств зі спільно важливих питань, водночас запропоновано застосування застарілих та неефективних рішень. 3 подібною ситуацією стикаємось у політиках багатьох інших країн (Blok et al., 2016).

Попри загалом позитивний імідж та приклади, залишається чимало зауважень. Насамперед це стосується застосування концепції, яка не відповідає принципам ЕЦ3, а інколи їм відверто суперечить. Наглядним прикладом, дотичним до змін клімату, є енергетична політика, де ЕЗЦ вживається до практики "відновлення енергіï" (energy recovery), тобто спалювання відходів для отримання енергії (waste-to-energy), а також пропозиції щодо класифікації їх як відновлюваних джерел енергії (Malinauskaite et al., 2017; Lausselet et al., 2017). Сміттєспалювальні заводи є найдорожчим методом генерування енергії, що призводить до безповоротної втрати матеріалів (Gaia, 2012; Ecocycle, 2011). Повідомлення СС про перетворення відходів в енергію (ЕС, 2017) орієнтоване на перехід від спалювання до запобігання - пропонують утриматися від інвестицій у спалю- 
вання, поки немає чіткого уявлення про можливості мінімізації. Через будівництво сміттєспалювальних заводів теплові системи деяких країн Свропи, особливо Швеції, стали залежними від імпорту відходів, адже свої відходи вони переважно переробляють у цінну вторсировину, що зберігає в кілька разів більше енергії, ніж генерує спалювання відходів. Отже, сміттєспалювальні заводи знищують цінні ресурси, які можна повторно використовувати або переробляти. Водночас, це створює попит на відходи та перешкоджає формуванню належної культури серед населення. Сьогодні деякі представники бізнесу, політики та науки активно пропагують та вказують на високий потенціал цієї стратегії в рамках ЕЗЦ (Malinauskaite et al., 2017; Lausselet et al., 2017), втім в їх аналізі не враховуються в кілька разів більші затрати енергії на виробництво товарів, які вони пропонують спалювати. Зважаючи на тривалу історію сміттєспалювання та наявність потужного лобі цієї сфери у СС, ефективне застосування ЕЗЦ на міжнародному рівні потребує складних політичних, інфраструктурних і економічних рішень від розвинених країн.

Фрагментарне впровадження ЕЗЦ може відбуватися 3 масштабними і істотними екологічними та соціальними наслідками. Наприклад, у Швеції 49,8 \% відходів переробляється, але спалювання 49,5 \% відходів зменшує мотивацію до мінімізації сміття та інших практик ЕЗЦ, а за минулі роки обсяги перероблення майже не змінились, тоді як багато країн СС нарощують обсяги перероблення понад 50 \% (EEA, 2016), а численні міста Європи, які застосовують принципи "нуль відходів", досягають понад 80 \% роздільного збирання вторинної сировини за значно менших загальних обсягів відходів і продовжують покращувати ці показники (ZWE, 2018).

Останньою категорією є виклики глибини, пов'язані 3 філософськими, етичними та науковими засадами ЕЗЦ. Учені Korhonen, Honkasalo \& Seppälä (2018) розглядають такі обмеження концепції ЕЗЦ з перспективи екологічної економіки: термодинамічні, системні (просторові, часові), фізичні (пов'язані бумеранг-ефектами), управління та менеджменту (взаємодія між різними організаціями та сферами, менеджмент потоків матеріалів та енергії між різними секторами), культурних та соціальних дефініцій (особливості конструювання концепцій у різних соціальних та культурних контекстах), а також обмеження внаслідок залежності від попереднього шляху. Неврахування термодинамічних обмежень $\epsilon$ істотним аспектом ЕЗЦ та дає змогу використовувати концепцію в рамках ідеології необмеженого зростання, несумісність якої з довготерміновою сталістю було неодноразово доведено школою екологічної економіки (Kallis, 2011; Daly, 2013). Суміжною проблемою є часте використання концепції насамперед 3 погляду генерування додаткових доходів, а не руху до сталості, що може призвести до ігнорування етичних, екологічних чи соціальних аспектів. Однією з причин цих застережень може бути багатоманіття розумінь та визначень ЕЗЦ (Kirchherr, Reike \& Hekkert, 2017), що залишає ЕЗЦ "збіркою розмитих та відокремлених ідей 3 кількох сфер та на половину наукових концепцій" (Korhonen, Honkasalo \& Seppälä, 2018).

Ключовими способами подолання існуючих викликів $є$ узгодження базових принципів ЕЗЦ незалежно від контексту, оцінювання кожного проекту щодо внеску до глобальної сталості, дотримання ієрархії використання природних ресурсів, розкриття усіх потенційних ризиків, системне врахування біологічних та технологічних складових життєвого циклу. ЕЗЦ починає діяти тільки за цілісного підходу, орієнтації на істотні та проривні практики, а не ті, які найлегше втілювати за певних умов.

Глибшого вивчення потребують можливості застосування концепції ЕЗЦ для пом'якшення змін клімату в межах різних галузей, інституційні аспекти впровадження концепції (Merli, Preziosi \& Acampora, 2018). Необхідно налагодити міжсекторальні та міжгалузеві партнерства, творити зв'язки між споживачами та виробниками, взаємодія яких $є$ передумовою успіху стратегії ЕЗЦ. Тільки за науково обгрунтованого застосування концепції ЕЗЦ її внесок у пом'якшення та адаптацію до змін клімату допоможе досягти бажаних цілей.

Висновки. Концепція ЕЗЦ швидко набуває глобальної популярності та стає одним із ключових чинників реалізації цілей Паризької угоди. У контексті змін клімату, концепція ЕЗЦ дає змогу ефективно втілювати нові підходи та звертає увагу на істотні взаємозв'язки між різними сферами людської діяльності, а також пропонує нову теоретико-методологічну основу для вирішення кліматичних викликів. Політикам, органам влади, науковцям та представникам бізнесу варто зважати на зв'язки та можливі синергії між енергетичною, ресурсною та іншими політиками в рамках цілісної політики сталості, а також на потоки природних ресурсів між різними секторами та галузями. Не менш важливим $\epsilon$ використання комунікативного потенціалу концепції у налагодженні діалогу між зацікавленими сторонами, спільність інтересів яких актуалізується у світлі виявлених взаємозв'язків. Для ефективного досягнення кліматичних цілей та уникнення негативних ефектів концепцію ЕЗЦ потрібно втілювати відповідно до науково обгрунтованих засад.

\section{Перелік використаних джерел}

Blok, K., Hoogzaad, J., Ramkumar, S., Ridley, A., Srivastav, P., Tan, I., Terlouw, W., \& de Wit., M. (2016). Implementing circular economy globally makes Paris target achievable. Circle Economy \& Ecofys. Retrieved from: https://www.circle-economy.com/. Accessed: 28.03 .2018

Bocken, N., De Pauw, I., Bakker, C., \& Van Der Grinten, B. (2016). Product design and business model strategies for a circular economy. Journal of Industrial and Production Engineering, 1-13. https://doi.org/10.1080/21681015.2016.1172124

Daly, H. (2013). A further critique of growth economics. Ecological Economics: The Transdisciplinary Journal of the International Society for Ecological Economics, 20-24.

EC (2015). Closing the Loop - An EU Action Plan for the Circular Economy. Communication from the Commission to the European Parliament. The Council, the European Economic and Social Committee and the Committee of the Regions.

EC (2017). The role of waste-to-energy in the circular economy. Communication from the Commission to the European Parliament, the Council, the European Economic and Social Committee and the Committee of the Regions.

Ecocycle (2011). Waste OF Energy. Why incineration is wrong for our environment, economy and community. Retrieved from: http://www.ecocycle.org. Accessed: 28.03.2018

EEA (2016). Waste recycling. European Environmental Agency. Retrieved from: https://www.eea.europa.eu. Accessed: 28.03.2018 
EMF (2015). Delivering the circular economy. A toolkit for policymakers. Ellen MacArthur Foundation. Retrieved from: https://www.ellenmacarthurfoundation.org. Accessed: 28.03.2018

GAIA (2012). Incinerators. Myths vs. Facts about "Waste to Energy". Retrieved from: http://www.no-burn.org. Accessed: 28.03.2018

Geneletti \& Zardo. (2016). Ecosystem-based adaptation in cities: An analysis of European urban climate adaptation plans. Land Use Policy, 50, 38-47. https://doi.org/10.1016/j.landusepol.2015.09.003

Huitema, D., Adger, W. N., Berkhout, F. G. H., Massey, E. E., Mazmanian, D., Munaretto, S., ... Termeer, C. C. J. A. M. (2016). The governance of adaptation: choices, reasons, and effects. Introduction to the Special Feature. Ecology and Society, 21(3), https://doi.org/10.5751/ES-08797-210337

Kallis, G. (2011). In defence of degrowth. Ecological Economics, 70(5), 873-880. https://doi.org/10.1016/j.ecolecon.2010.12.007

Kirchherr, J., Reike, D., \& Hekkert, M. (2017). Conceptualizing the circular economy: An analysis of 114 definitions. Resources, Conservation \& Recycling, 127, 221-232. https://doi.org/10.1016/j.resconrec.2017.09.005

KMU (2016). Kontseptsiia derzhavnoi polityky u sferi zminy klimatu na period do $2030 \mathrm{roku}$. Retrieved from: http://www.kmu.gov.ua/. Accessed: 28.03.2018. [In Ukrainian].

KMU (2017). Natsionalna stratehiia upravlinnia vidkhodamy v Ukraini do 2030. Retrieved from: https://menr.gov.ua. Accessed: 28.03.2018. [In Ukrainian].

KMU (2017). Plan shchodo vykonannia Kontseptsii realizatsii derzhavnoi polityky u sferi zminy klimatu na period do 2030 roku. Retrieved from: http://www.kmu.gov.ua/ Acessed: 28.03.2018. [In Ukrainian].

Korhonen, J., Honkasalo, A., \& Seppälä, J. (2018). Circular Economy: The Concept and its Limitations. Ecological Economics, 143, 37-46. https://doi.org/10.1016/j.ecolecon.2017.06.041

Lausselet, C., Cherubini, F., Oreggioni, G. D., Del Alamo Serrano, G., Becidan, M, Hu, X., Rørstad, P. Kr., \& Strømman, Anders H. (2017). Norwegian Waste-to-Energy: Climate change, circular economy and carbon capture and storage. Resources, Conservation \& Recycling, 126 ,

$50-61$. https://doi.org/10.1016/j.resconrec.2017.07.025

Lewandowski, M. (2016). Designing the Business Models for Circular Economy - Towards the Conceptual Framework. Sustainability, 8(1), 1-28. https://doi.org/10.3390/su8010043

Malinauskaite, J., Jouhara, H., Czajczyńska, D., Stanchev, P., Katsou, E., Rostkowski, P., Thorne, R. J., Colón, J., Ponsá, S., Al-Mansour, F., Anguilano, L., Krzyżyńska, R., López, I. C., A. Vlasopoulos, N., $\&$ Spencer, N. (2017). Municipal solid waste management and waste-to-energy in the context of a circular economy and energy recycling in Europe. Energy, 141, 2013-2044. https://doi.org/10.1016/j.energy.2017.11.128
Mcdonough, W. (2016). Carbon is not the enemy. Nature, 539(7629), 349-351. https://doi.org/10.1038/539349a

McDonough, W., \& Braungart, M. (2002). Cradle to cradle: Remaking the way we make things. (1st ed.). New York: North Point Press.

McDonough, W., \& Braungart, M. (2013). The upcycle: Beyond sustainability: Designing for abundance. (1st ed.). New York: North Point Press.

MENR (2017). Proekt Stratehii nyzkovuhletsevoho rozvytku Ukrainy do 2050 roku. Retrieved from: https://menr.gov.ua. Accessed: 28.03.2018. [In Ukrainian].

Merli, R., Preziosi, M., \& Acampora, A. (2018). How do scholars approach the circular economy? A systematic literature review. $J_{o-}$ urnal of Cleaner Production, 178, 703-722. https://doi.org/10.1016/j.jclepro.2017.12.112

Murray, A., Skene, Keith \& Haynes, Kathryn. (2017). The circular economy an interdisciplinary exploration of the concept and application in a global context. Journal of Business Ethics: JOBE, 140(3), 369-380.

Pauli, G. A. (2010). The Blue economy: 10 years, 100 innovations, 100 million jobs. Paradigm Pubns.

Pearce, D., \& Turner, R. (1990). Economics of natural resources and the environment. Baltimore: Johns Hopkins University Press.

Ramkamur, S. (2017). The fourth industrial revolution and the circular economy. Circulate. Retrieved from: http://circulatenews.org/. Accessed: 28.03.2018

Simon, J. M. (2015). Zero Waste - a Key Solution for a Low-Carbon Economy. Zero Waste Europe. Retrieved from: https://zerowasteeurope.eu. Accessed: 28.03.2018

Stern, N. (2013). A Blueprint for a safer planet how we can save the world and create prosperity. New York: Vintage Books.

UNEP (2017). Emissions Gap Report 2017: A UN Environment Synthesis Report. United Nations Environment Programme (UNEP), Nairobi

WEF (2014). Towards the Circular Economy: Accelerating the scaleup across global supply chains. World Economic Forum. Geneva, Switzerland.

Wijkman, A., Skånberg, K., Berglund, M., \& Club of Rome. (2015). The circular economy and benefits for society: Jobs and climate clear winners in an economy based on renewable energy and resource efficiency: A study pertaining to Finland, France, the Netherlands, Spain and Sweden. Winterthur: Club of Rome.

Winans, Kendall \& Deng. (2017). The history and current applications of the circular economy concept. Renewable and Sustainable Energy Reviews, 68, 825-833. https://doi.org/10.1016/j.rser.2016.09.123

ZWE (2018). Network of European Zero Waste Municipalities. Zero Waste Europe. Retrieved from: http://zerowasteeurope.eu/zerowastecities.eu/. Accessed: 28.03.2018.

В. И. Соловий
Львов, Украина

\title{
ЗНАЧЕНИЕ ЭКОНОМИКИ ЗАМКНУТЫХ ЦИКЛОВ ДЛЯ СМЯГЧЕНИЯ И АДАПТАЦИИ К ИЗМЕНЕНИЯМ КЛИМАТА: ГЛОБАЛЬНЫЕ ТЕНДЕНЦИИ, ВОЗМОЖНОСТИ И ПРЕДОСТЕРЕЖЕНИЯ
}

\begin{abstract}
Экономика замкнутых циклов является концепцией управления ресурсами, которая стремительно набирает глобальную популярность и может совсем скоро стать ключевым двигателем для достижения целей Парижского соглашения. Рассмотрены возможности и предостережения относительно применения научно обоснованной концепции экономики замкнутых циклов для мероприятий по смягчению и адаптации к изменениям климата. Обоснован вклад экономики замкнутых циклов к новому пониманию изменений климата, в углубление и расширение спектра решений в этой сфере, выявление новых взаимосвязей между различными отраслями и секторами, а также применение этих возможностей для прорывных и инновационных практик, которые максимизируют положительные результаты и сводят к минимуму экологические риски. Проанализированы особенности концепции экономики замкнутых циклов, которые способствуют привлечению широкого круга заинтересованных сторон (представителей органов власти, бизнеса, науки, общественности) и активному диалогу между ними. Обращено внимание на существенные аспекты применения концепции для смягчения и адаптации к изменениям климата, возможности для синергий между энергетической, экономической, экологической, ресурсной и другими политиками в более широких рамках целостной политики устойчивости. Выяснены ограничения и актуальные вызовы, связанные с толкованием, практическим воплощением и научными принципами концепции. Предложены ключевые направления применения экономики замкнутых циклов для стратегий по смягчению и адаптации к изменениям климата.
\end{abstract}

Ключевые слова: экологическая экономика; устойчивое развитие; инновации; технологии; управление. 
THE SIGNIFICANCE OF CIRCULAR ECONOMY FOR CLIMATE CHANGE MITIGATION AND ADAPTATION: GLOBAL TRENDS, POSSIBILITIES AND PRECAUTIONS

Circular economy, a concept concerned with resource optimization in line with the natural cycles, is rapidly gaining global prominence and may soon become a key force in reaching the goals of the Paris Agreement. The authors explore the possibilities of using circular economy concept for mitigating and adapting to climate change. Circular economy stimulates new ways of thinking about climate change and expands the spectrum of solutions in the sphere, as well as opens up new space for using these possibilities to create breakthrough and innovative practices, maximizing positive impacts and minimizing ecological risks. The concept enables articulating new approaches, draws attention to the significant interconnections between different spheres and also offers a new language for addressing climate challenges. Politicians, authorities, academics and businesses dealing with climate change should consider the links and potential synergies between energy, economic, environmental, resource (regarding, in particular, waste) and other policies within the framework of a holistic sustainability policy, as well as resource flows between different sectors and industries. The use of the communicative potential of the concept in establishing a dialogue between the parties concerned is equally important, as the concept brings to the forefront important ecological-economic knowledge in a way that business and political leaders can easily comprehend and use. At the same time, one should be careful about the distorted applications of the concept. We focus on the challenges the concept of circular economy brings about, along with the limitations it faces, breaking them into three categories - interpretation, use and scientific rigor. While still in the formation stage, circular economy might be used without consideration of deeper environmental, social or ethical aspects, and therefore it is important to develop the concept based on foundations derived from ecological economics and sustainability science, without sacrificing its innovative nature and intuitive comprehensibility for a wide range of stakeholders.

Keywords: ecological economics; sustainability; innovation; technologies; governance. 